\title{
Ten Centuries of Salt Mining
}

\section{in Poland}

\section{by Waclaw Ryka and Zbigniew Werner}

\begin{abstract}
Salt production at Wieliczka in southern Poland covers nearly a millennium of recorded history. The mines played a major role in Poland's economy from the 14th to the l8th Century, and their grandeur and architecture were already attracting foreign visitors by the end of the l400s. Wieliczka provides an exceptional example and a primary documentary source on mining, its rich collection of mining tools and equipment tracing the evolution of mining techniques and the salt industry over the centuries. The mine also contains unique works of art such as underground chapels and statues hewn from rock salt. For these reasons the Wieliczka mine was declared a World Heritage site by unesco in 1978. This article summarizes the geology of the salt deposits and the historical development of the mine. (Ed.)
\end{abstract}

History of Salt Mining at Wieliczka

Fifteen kilometres southeast of Cracow is the city of Wieliczka (Fig. 1), built on an ancient salt mine located at depths extending from 63 to 327 metres below the surface. The workings (galleries, slopes, pits, ponds, shafts) are

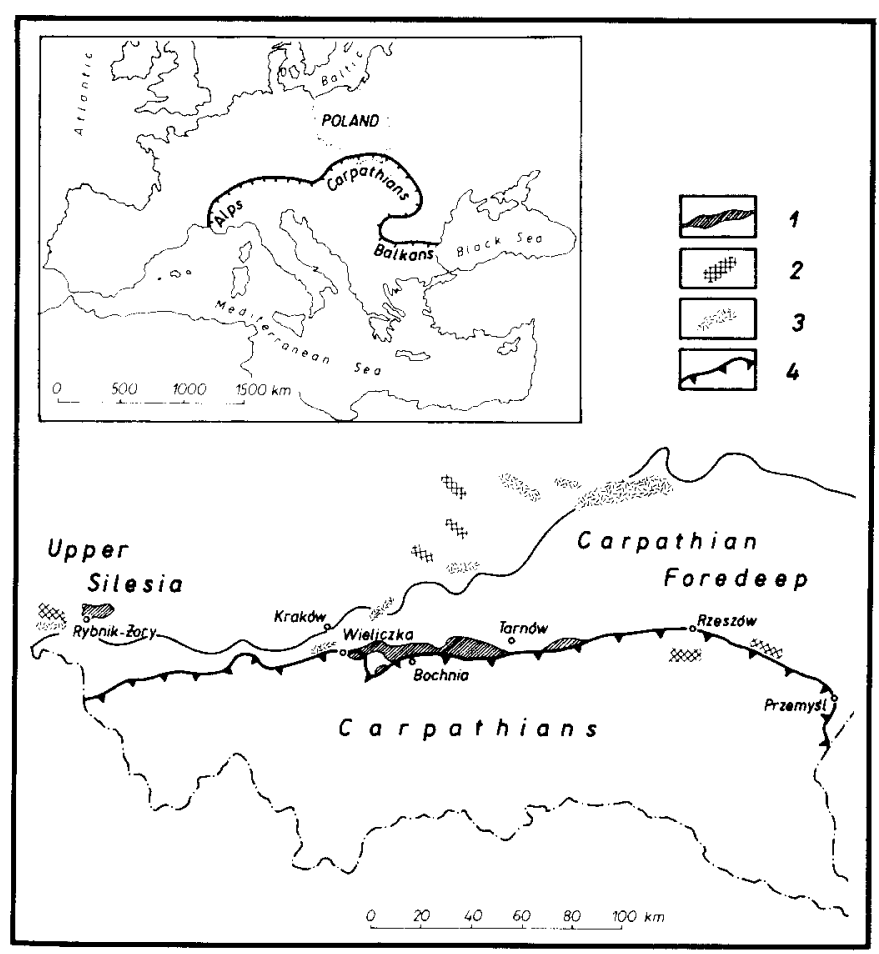

Figure 1: Distribution of the Miocene salt-bearing formation in the Polish part of the Carpathian Foredeep. I- rock salt, 2- anhydrite and gypsum, 3native sulphur deposits, 4- Carpathian overthrust.

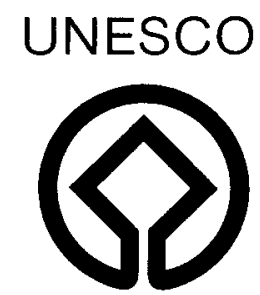

World Heritage Site

situated on nine different levels with a total length of some $300 \mathrm{~km}$. Salt production here probably began in the Neolithic period, but the first records show that organized salt manufacturing from saline springs and wells commenced in 1105 under the supervision of Benedictine monks who had been granted a licence in 1044. Large-scale salt mining did not develop until 1290 when Wieliczka obtained its municipal statute, and "Magnum Salalias Wieliczka" became a property of the King of Poland. From then to the 18th Century, profits from the salt mines made up a third of the Royal income and were used to rebuild the Wawel Renaissance castle in Cracow, a number of churches, the town's defence walls and many municipal buildings.

Between the 13th and 18th Centuries, the Cracow salt mines constituted the largest industry in Poland and, indeed, one of the largest enterprises in the world, in view of the number of workers involved, rising from about 200 men in the 14 th Century, 500 in the 16 th to some 1,300 at the start of the 18 th Century. At this time about 30,000 tons of salt were mined annually, and growth of the salt market in the years 1811-1813 resulted in an increase of production of nearly 95,000 tons per year. A similar level of mining was achieved in 1913, when 1,600 men were employed. After World War I, Wieliczka produced between 117,000 and 196,000 tons annually, and in its most productive years, 1964-1974, the output increased to about 256,000 tons per year.

\section{Geological Setting}

The Wieliczka deposit occurs in a Miocene salt-bearing formation that stretches from Upper Silesia through Cracow, Tarnow and Przemysl and into the Ukraine and Romania as far as the Black Sea (Fig. 1). In Poland this formation is of Tortonian age and rests unconformably on Carboniferous rocks in Upper Silesia, on Jurassic and Cretaceous flysch in the region of Cracow and Tarnow, and on the Precambrian in southeastern Poland.

The salt-bearing formation consists mainly of clays and silts, up to $1,000 \mathrm{~m}$ thick, and contains in its lower part a salt member up to $300 \mathrm{~m}$ thick (Gawel, 1962). The salt originated in lakes and pans in a zone more than $10 \mathrm{~km}$ wide extending parallel to the present front of the Carpathian Mountains. Tectonic shortening during the northerly directed Alpine movements, which built the Carpathian Mountains, reduced this zone to a width of $1.5 \mathrm{~km}$, and the Tortonian rocks were recumbently folded so that the originally thin salt layers were in places greatly thickened in fold cores. Locally, the southern salt pans have been thrusted over the northern pans, effectively doubling the thickness of sait, and folding and overthrusting have resulted in a highly complicated structure 


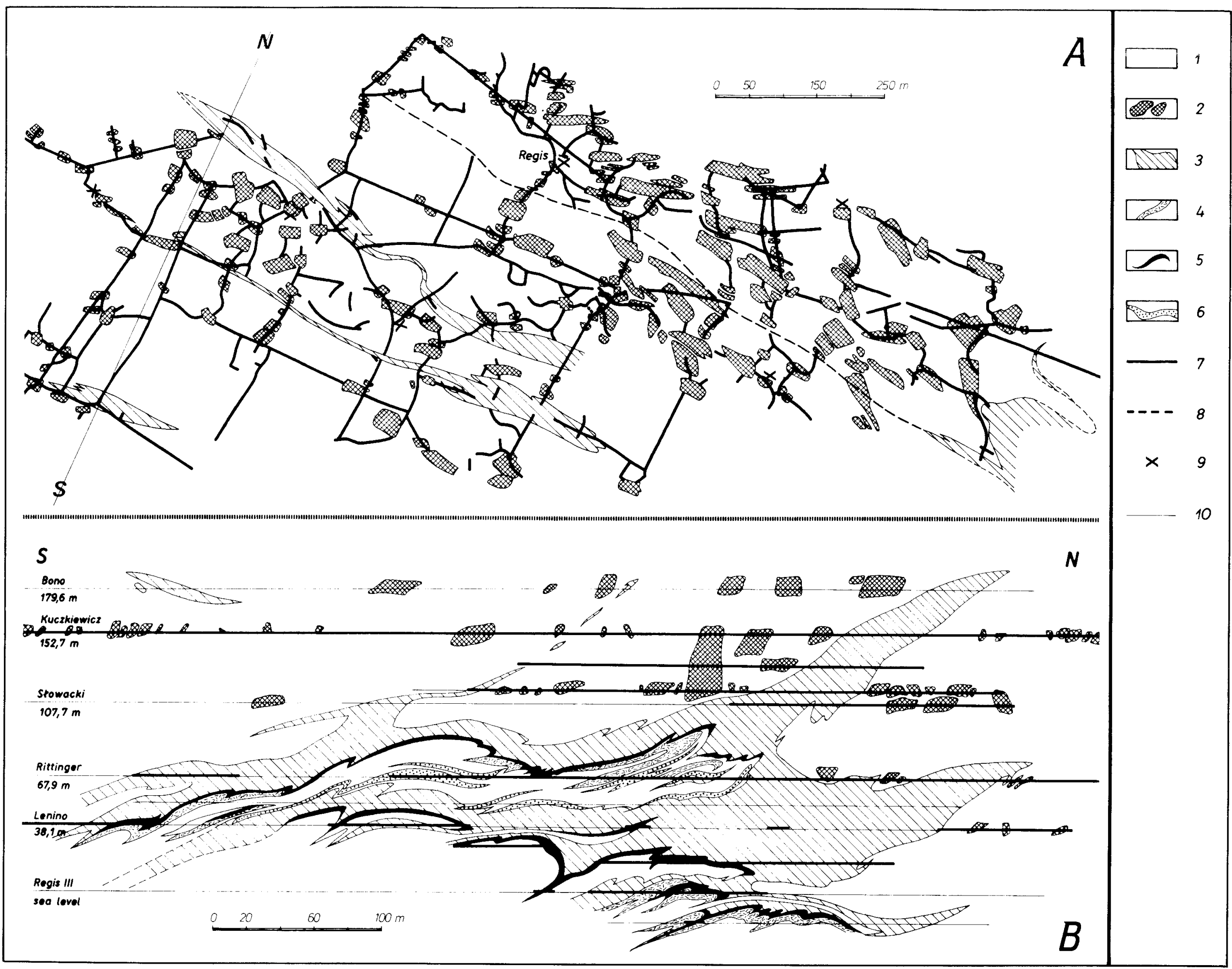


Figure 2: A) Plan of Level 1, the "Bono." 1saliferous clays and mudstones, 2- green salt megabreccia blocks, 3- "Spisa Salt," 4- "Shaft Salt," 5- layers of "Green Salt" with intercalations of clay and anhydrite, 6- sandstone, 7- galleries within the mine level, 8- galleries extending above mine level, 9- shafts, 10- location of cross-section B. B) Cross-section through the rock-salt deposits. After Gawel (1962).

(Fig. 2). The Wieliczka salt deposit can be grouped into two major divisions: the lower part, comprising rocks of the central and northern parts of the pan, is stratified, whereas the upper part is a blocky and rather irregular tectonic megabreccia (Gawel, 1967). Thrust planes display the effects of refolding and appear quite convoluted.

\section{Stratified Deposits}

The oldest Tortonian rocks of Wieliczka are represented by mudstones with tuff intercalations that underlie the oldest, so-called "Green Salt." The latter comprises three to five layers; the lowest is the thickest $(4 \mathrm{~m})$ and the others successively thinner $(3 \mathrm{~m}, 2 \mathrm{~m}, 1.3 \mathrm{~m}$ and $0.5 \mathrm{~m})$ with clay intercalations between $0.4 \mathrm{~m}$ and $\mathrm{l} \mathrm{m}$ thick. The salt is coarsely crystalline, with grains up to a few $\mathrm{cm}$ in size, and its characteristic greenish colour is due to the presence of small admixtures of clay. Anhydrite, gypsum crystals and gas and water bubbles are common. The Green Salt is thought to have crystallized relatively slowly under quiet conditions at depths of about $400-500 \mathrm{~m}$ in the central part of the lake. Anhydrite-bearing clays of constant thickness $(0.65-0.70 \mathrm{~m})$ together with the so-called "Shaft Salt" overlie the Green Salt.

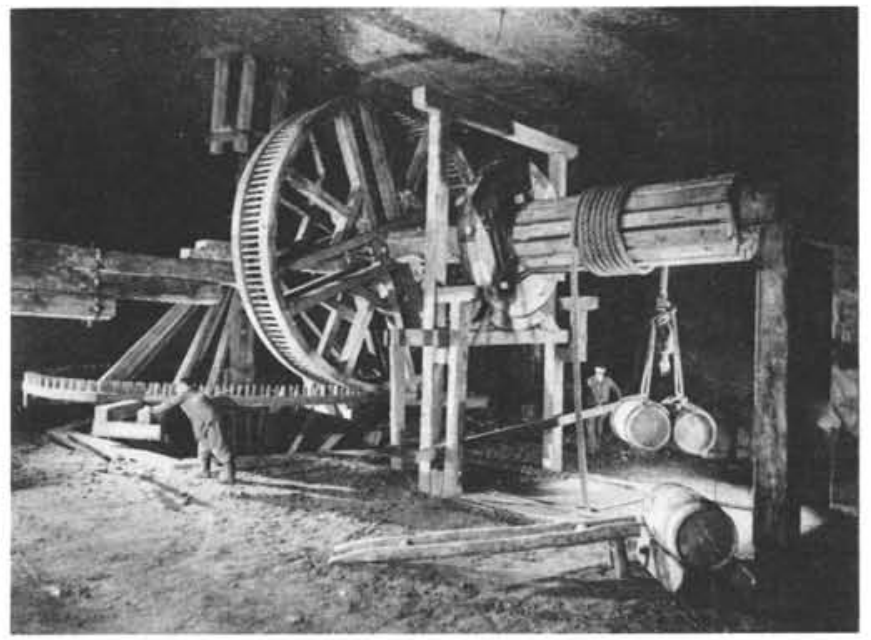

Figure 3: Horse-powered winch hoist from the 17th Century.

The Shaft Salt is traceable throughout the mine area. It is between 1.2 and $1.5 \mathrm{~m}$ thick and is unusually pure, the content of terrigenous material varying from 0.07 to $0.60 \%$ and ealcium sulphates from 0.3 to $0.9 \%$. It consists of $0.3-2.5$ $\mathrm{em}$ halite crystals of a light yellow colour. Crystallization of this salt is thought to have taken place in lakes under perfectly quiet conditions. The Shaft Salt is overlain by an intercalation of clays with anhydrite, 0.3 to $0.5 \mathrm{~m}$ thick.

The "Spisa Salt" is the youngest saline horizon in the stratified part of the Wieliczka deposit. It is up to $40 \mathrm{~m}$ thick and is composed of fine $(2.5-5.0 \mathrm{~mm})$, elongate, parallel halite crystals. The presence of many thin intercalations of clay, silt and organic materials suggests that the Spisa Salt erystallized rapidly. In its upper part, this salt becomes increasingly contaminated with sand and gradually passes into massive salty sandstone, rich in plant remains.

\section{Blocky Deposits}

The blocky deposits lie tectonically above the stratified deposits. They consist mainly of dark grey unstratified clays, which in places are slightly lighter in colour and contain single halite crystals up to a few $\mathrm{cm}$ long. These rocks are known by the name "zuber" (salt breccia - Gawel, 1967). In some places the crystals join with one another to form a rock that, as the amount of clay matter decreases, passes into typical green salt. However this type of green salt does not form stratified layers but isolated iceberg-like bodies varying from very small to about $18,000 \mathrm{~m}^{3}$ in size with irregular to rhomboidal shapes (Fig. 2). Their irregular distribution was the cause of the winding path followed by the mine galleries. The green salt forming these bodies is fairly pure, with a clay content varying from 0.7 to $3.108,1.98$ being the average.

Mining Techniques

In the beginning, salt in the Wieliczka mine was excavated manually from various depths down to $60 \mathrm{~m}$. The oldest is the Regis Shaft, known to have been worked as early as the first half of the 13th Century. By the end of the 17th Century, there were ten working shafts. The first exploitation level, called the "Bono," originated when the shafts were connected by galleries. Individual salt bodies of the Blocky Deposits were then exploited, some of them for a period of two centuries.

Salt was broken off the walls with wedges and worked with axes to form "snowmen" of various sizes and kinds. These cylindrical blocks weighed between 200 and $300 \mathrm{~kg}$ each.

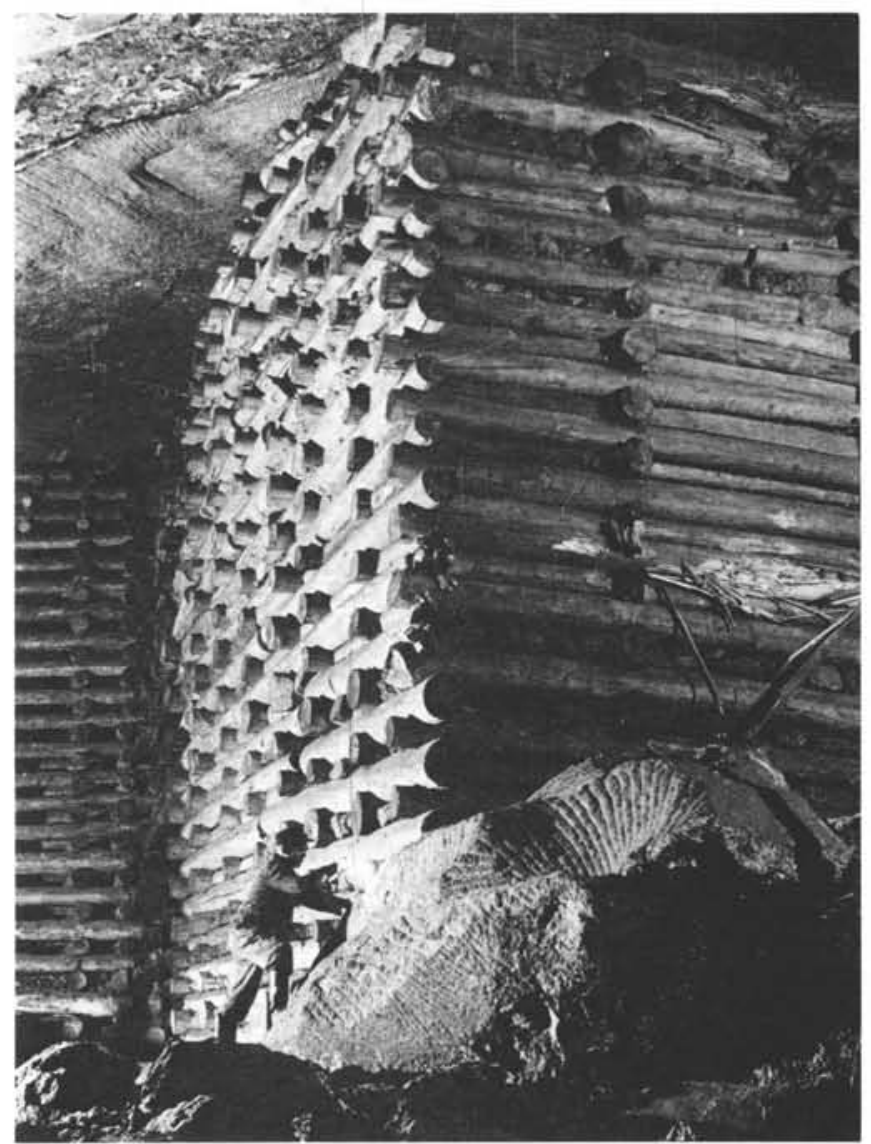

Figure 4: A pillar made of alternating layers of tree trunks. 
With time the snowmen sizes were fixed: Cracow snowmen (for the home market) measured $55 \mathrm{~cm}$ wide and $165 \mathrm{~cm}$ long, whereas Oswiecim snowmen (for export) were lighter in colour and half the size of the former. The waste from the production of snowmen and the undersized salt blocks were sold in barrels. In addition, salt was sold in blocks of variable sizes and also in crystalline form after evaporation from saturated brines.

The salt was initially brought to the surface manually. Around 1400 AD, horse-powered winch hoists were introduced, and by 162081 horses were working in the mine (Fig. 3). Until the 16 th Century, mining was carried out in the spring and winter only, with two eight-hour shifts. Working conditions and salaries were good for these times but became worse in the 17 th Century when the work was carried out all the year round.

Where salt linings were left to support the walls, many chambers from the 16 th Century have survived to the present day. Large chambers were protected with salt pillars or timber constructions called "cases" (Fig. 4). Once exploitation of salt deposits on the first level was complete, deep shafts were constructed allowing exploitation to continue at lower levels. Collapse of one of the chambers resulted in

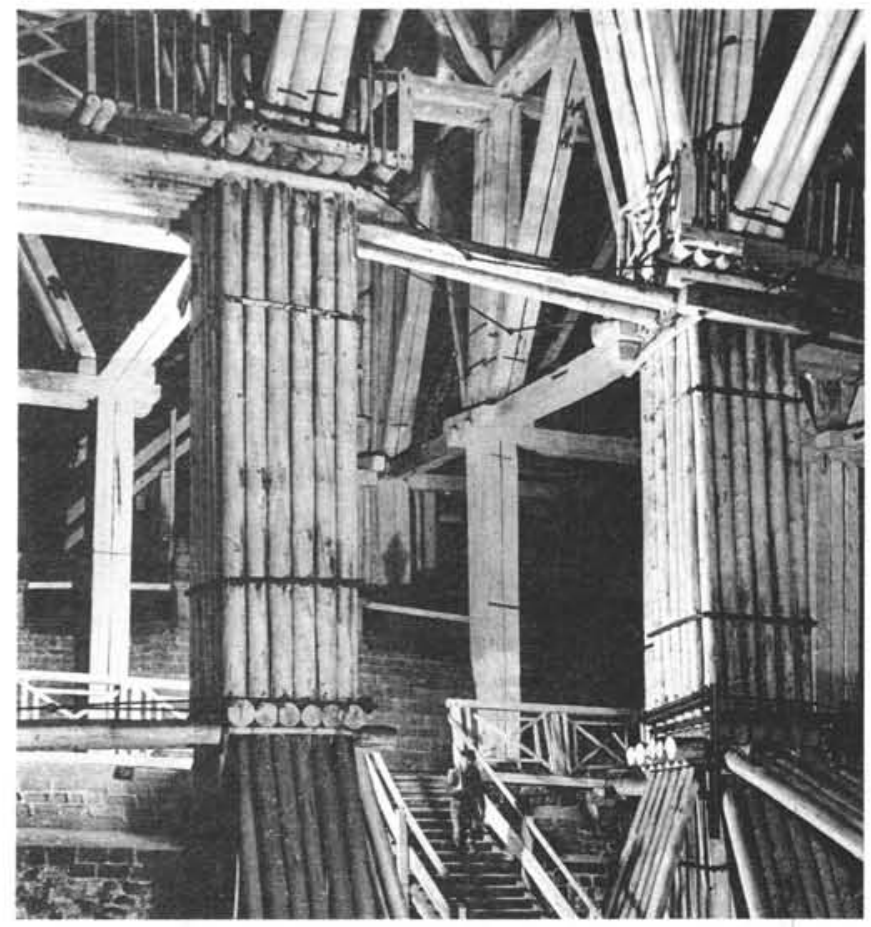

Figure 5: A wooden abutment in the 17th Century Michalowice chamber.

compilation of the first recorded mine plan in 1638; the "Filum Ariadnae in Lybyrintho Vielicensi" by the Swedish surveyor Martin German. In seven years he made five very accurate plans at the scale of 1:1220, which are among the oldest mine plans in Europe.

The collection of maps of the Wieliczka mine has grown to 3,000 and constitutes the largest eartographic collection in Poland. In 1976, the mine was included in the register of national monuments, and in 1978 it was placed on the first list of Unesco World Natural and Cultural Heritage sites.

At present, the Museum of the Cracow Salt-Mines organizes tours of works ranging from the 17th to the 20th Centuries. The $2.6 \mathrm{~km}$ long route includes 19 mining chambers on the first and third levels at Wieliczka. The part accessible to visitors represents only $2 \%$ of the whole labyrinth of chambers and galleries of nine exploitation levels and over $200 \mathrm{~km}$ of tunnels.
One of the most magnificent chambers is St. Anthony's Chapel, excavated by a miner-sculptor in the 16th Century, and there is also a beautiful Chapel of St. Kinga (cover photo) illuminated with chandeliers made of crystalline salt. In the Erasm Baraca cave, exploited during the 17th and 18th Centuries, the attractions include a salt lake and a huge salt pillar supporting the roof. In ancient times, thieves stealing salt from such pillars were punished by cutting off their arms. In the Michalowice chamber, a $64 \mathrm{~m}$ high wooden abutment, a masterpiece of timberwork is preserved (Fig. 5). In the Michal-Saurau complex there is a sophisticated architecture of mine workings including pillars and galleries ascending upwards in the form of staircases. In other chambers there is a unique exhibition of ancient mining techniques. The number of visitors has now reached about 700,000 per year.

The Wieliczka mine is still actively producing salt from its deeper levels at a rate of 230,000 tons per year. Since 1826 , the mine has been used as a health resort for patients with respiratory diseases: several chambers are used as a hospital and about a thousand patients receive treatment here every year.

Prof. W. Ryka is Director of the Geological Insitute (ul. Rakowiecka 4, 00-975 Warsaw, Poland). His main research has been on Preeambrian crystalline rocks and especially on V-bearing titanomagnetite ores. He has served as geological consultant in Nigeria, Mongolia and Algeria.

Dr. Z.H. Werner is Head of the Economic Geology Department of the Geological Institute in Warsaw. A specialist on salt deposits, he has worked in Libya, Algeria and Iraq, and was responsible for the discovery of several salt and potash deposits.
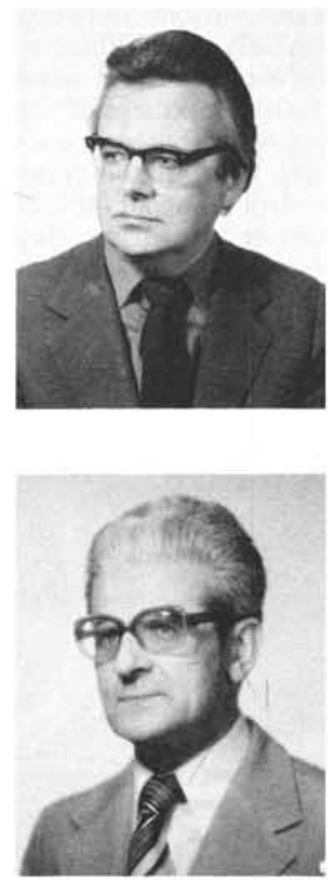

\section{References}

Gawel, A., 1962. The geological structure of the Wieliczka Salt Deposit. Instytut Geologiczny Prace, Warsaw, v. 30, p. 305-332. In Polish with English summary.

Gawel, A., 1967. Salt Deposit at Wieliczka. Instytut Geologic zny Biuletyn 211, Warsaw, p. 325-328. 